\title{
Front Matter: Volume 7911
}

, "Front Matter: Volume 7911," Proc. SPIE 7911, Plasmonics in Biology and Medicine VIII, 791101 (6 April 2011); doi: 10.1117/12.888803

SPIE. Event: SPIE BiOS, 2011, San Francisco, California, United States 


\title{
Plasmonics in Biology and Medicine VIII
}

\author{
Tuan Vo-Dinh \\ Joseph R. Lakowicz \\ Editors
}

23-24 January 2011

San Francisco, California, United States

Sponsored and Published by

SPIE 
The papers included in this volume were part of the technical conference cited on the cover and title page. Papers were selected and subject to review by the editors and conference program committee. Some conference presentations may not be available for publication. The papers published in these proceedings reflect the work and thoughts of the authors and are published herein as submitted. The publisher is not responsible for the validity of the information or for any outcomes resulting from reliance thereon.

Please use the following format to cite material from this book:

Author(s), "Title of Paper," in Plasmonics in Biology and Medicine VIII, edited by Tuan Vo-Dinh, Joseph R. Lakowicz, Proceedings of SPIE Vol. 7911 (SPIE, Bellingham, WA, 2011) Article CID Number.

ISSN 1605-7422

ISBN 9780819484482

Published by

SPIE

P.O. Box 10, Bellingham, Washington 98227-0010 USA

Telephone +1 3606763290 (Pacific Time) · Fax +1 3606471445

SPIE.org

Copyright (C) 2011, Society of Photo-Optical Instrumentation Engineers.

Copying of material in this book for internal or personal use, or for the internal or personal use of specific clients, beyond the fair use provisions granted by the U.S. Copyright Law is authorized by SPIE subject to payment of copying fees. The Transactional Reporting Service base fee for this volume is $\$ 18.00$ per article (or portion thereof), which should be paid directly to the Copyright Clearance Center (CCC), 222 Rosewood Drive, Danvers, MA 01923. Payment may also be made electronically through CCC Online at copyright.com. Other copying for republication, resale, advertising or promotion, or any form of systematic or multiple reproduction of any material in this book is prohibited except with permission in writing from the publisher. The CCC fee code is 1605$7422 / 11 / \$ 18.00$.

Printed in the United States of America.

Publication of record for individual papers is online in the SPIE Digital Library.

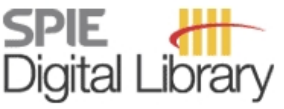

SPIEDigitalLibrary.org

Paper Numbering: Proceedings of SPIE follow an e-First publication model, with papers published first online and then in print and on CD-ROM. Papers are published as they are submitted and meet publication criteria. A unique, consistent, permanent citation identifier (CID) number is assigned to each article at the time of the first publication. Utilization of CIDs allows articles to be fully citable as soon they are published online, and connects the same identifier to all online, print, and electronic versions of the publication. SPIE uses a six-digit CID article numbering system in which:

- The first four digits correspond to the SPIE volume number.

- The last two digits indicate publication order within the volume using a Base 36 numbering system employing both numerals and letters. These two-number sets start with 00, 01, 02, 03, 04, $05,06,07,08,09,0 A, 0 B \ldots$. 0Z, followed by 10-1Z, 20-2Z, etc.

The CID number appears on each page of the manuscript. The complete citation is used on the first page, and an abbreviated version on subsequent pages. Numbers in the index correspond to the last two digits of the six-digit CID number. 


\section{Contents}

vii Conference Committee

\section{SURFACE ENHANCED RAMAN SCATTERING}

791102 Manipulation of silver nanoparticles in a droplet for label-free detection of biological molecules using surface enhanced Raman scattering [7911-01]

M. Çulha, M. Altunbek, S. Keskin, D. Saatçi, Yeditepe Univ. (Turkey)

791103 Numerical optimization of periodic hole arrays for plasmonic Raman sensor [7911-02] K. Yamaguchi, Toyohashi Univ. of Technology (Japan); M. Fujii, Toba National College of Maritime Technology (Japan); D. K. Gramotnev, Nanophotonics Pty Ltd. (Australia); M. Fukuda, Toyohashi Univ. of Technology (Japan)

791105 Paper-based optofluidic SERS using ink-jet-printed substrates [7911-04]

W. W. YU, I. M. White, Univ. of Maryland, College Park (United States)

791107 Classification of bacterial samples as negative or positive for a UTI and antibiogram using surface enhanced Raman spectroscopy [7911-03]

E. Kastanos, Univ. of Nicosia (Cyprus); K. Hadjigeorgiou, A. Kyriakides, C. Pitris, Univ. of Cyprus (Cyprus)

791108 Portable surface-enhanced Raman spectroscopy for insecticide detection using silver nanorod film fabricated by magnetron sputtering [7911-05]

K. Wong-ek, Chulalongkorn Univ. (Thailand); M. Horprathum, P. Eiamchai, P. Limnonthakul, V. Patthanasettakul, P. Chindaudom, N. Nuntawong, National Electronics and Computer Technology Ctr. (Thailand)

\section{SURFACE PLASMON RESONANCE AND SENSING I}

7911 OB Enhanced SPR sensing based on micropatterned thin films [7911-10]

L. S. Live, J. Breault-Turcot, K.-L. Nguyen, J.-F. Masson, Univ. de Montréal (Canada)

$79110 \mathrm{C}$ Surface plasmon resonance biosensing via differential spectral phase interferometry [7911-11]

S.-P. Ng, C.-M. L. Wu, City Univ. of Hong Kong (Hong Kong, China); S.-Y. Wu, H.-P. Ho,

S.-K. Kong, The Chinese Univ. of Hong Kong (Hong Kong, China)

\section{SURFACE PLASMON RESONANCE AND SENSING II}

$79110 \mathrm{O}$ Aptamer-based localized surface plasmon resonance sensor for monitoring glycated proteins [7911-13]

R. Zheng, B. D. Cameron, The Univ. of Toledo (United States) 
7911 OF Development of a molecularly imprinted polymer based surface plasmon resonance sensor for theophylline monitoring [7911-14]

R. Zheng, B. D. Cameron, The Univ. of Toledo (United States)

\section{APPLICATIONS OF PLASMONICS II}

7911 ON Hybrid gold nanorods/polysaccharides composites as new materials for photothermal applications [7911-22]

P. Matteini, F. Ratto, F. Rossi, R. Pini, Istituto di Fisica Applicata Nello Carrara (Italy)

7911 OP Photothermally activated drug release from liposomes coupled to hollow gold nanoshells [7911-24]

N. Forbes, Univ. of California, Santa Barbara (United States); J. A. Zasadzinski, Univ. of Minnesota (United States)

7911 OR Single-fullerene manipulation inside a carbon nanotube [7911-26]

O. E. Glukhova, I. V. Kirillova, I. N. Saliy, M. M. Slepchenkov, N.G. Chernyshevsky Saratov

State Univ. (Russian Federation)

FLUORESCENCE, PLASMONICS, AND IMAGING

7911 OS Hyperspectral molecular imaging of multiple receptors using immunolabeled plasmonic nanoparticles [7911-07]

M. J. Crow, K. Seekell, S. Marinakos, Duke Univ. (United States); J. Ostrander, Univ. of Minnesota Cancer Ctr. (United States); A. Chilkoti, A. P. Wax, Duke Univ. (United States)

7911 OT Ultra-sensitive plasmonic nanosensors for biochemical detection [7911-28]

J. Martin, J. Proust, D. Gérard, J.-L. Bijeon, J. Plain, P. Royer, Lab. de Nanotechnologie et

d'Instrumentation Optique, CNRS, Univ. de Technologie de Troyes (France)

\section{IMAGING AND PLASMONICS}

$79110 X$ Boosting detection sensitivity by using a surface-wave-enabled darkfield aperture (SWEDA) [7911-32]

G. Zheng, S. Yang, C. Yang, California Institute of Technology (United States)

7911 OY Triply surface-plasmon resonant four-wave mixing imaging of gold nanoparticles [7911-33] F. Masia, W. Langbein, P. Watson, P. Borri, Cardiff Univ. (United Kingdom)

791110 Silver plasmon rulers as probes in polarization-resolved plasmon coupling microscopy [7911-35]

H. Wang, G. Rong, L. Yang, B. M. Reinhard, Boston Univ. (United States)

PLASMONICS, STRUCTURES, AND PHOTOPHYSICS

$791114 \quad$ Novel monolayer and bilayer shell aggregate gold nanostructures [7911-37]

M. Angelidou, C. Pitris, Univ. of Cyprus (Cyprus) 
791117 Experimental analysis of optical resonance transmission properties of sub-wavelength hole arrays in optically thick metal films [7911-40]

M. Najiminaini, Simon Fraser Univ. (Canada) and Lawson Health Research Institute (Canada); F. Vasefi, Simon Fraser Univ. (Canada), Lawson Health Research Institute (Canada), and Univ. of Western Ontario (Canada); B. Kaminska, Simon Fraser Univ. (Canada); J. J. L. Carson, Lawson Health Research Institute (Canada) and Univ. of Western Ontario (Canada)

791118 Effect of adhesion layer on optical resonance transmission properties of nano-hole arrays in an optically thick gold film [7911-41]

M. Najiminaini, Simon Fraser Univ. (Canada) and Lawson Health Research Institute (Canada); F. Vasefi, Simon Fraser Univ. (Canada), Lawson Health Research Institute (Canada), and Univ. of Western Ontario (Canada); B. Kaminska, Simon Fraser Univ. (Canada); J. J. L. Carson, Lawson Health Research Institute (Canada) and Univ. of Western Ontario (Canada)

POSTER SESSION

7911 1A Fabrication of photonic force devices for biomolecule dynamics [7911-43]

S. S. Choi, SunMoon Univ. (Korea, Republic of); M. J. Park, Korea Military Academy (Korea, Republic of); D. Kim, N. Park, Seoul National Univ. (Korea, Republic of); L. Lee, Univ. of California, Berkeley (United States)

7911 1C Combined near infrared photothermolysis and photodynamic therapy by association of gold nanoparticles and an organic dye [7911-46]

E. S. Tuchina, N.G. Chernyshevsky Saratov State Univ. (Russian Federation); F. Ratto, Istituto di Fisica Applicata Nello Carrara (Italy); B. N. Khlebtsov, Institute of Biochemistry and Physiology of Plants and Microorganisms (Russian Federation); S. Centi, Univ. degli Studi di Firenze (Italy); P. Matteini, F. Rossi, Istituto di Fisica Applicata Nello Carrara (Italy); F. Fusi, Univ. degli Studi di Firenze (Italy); N. G. Khlebtsov, Institute of Biochemistry and Physiology of Plants and Microorganisms (Russian Federation); R. Pini, Istituto di Fisica Applicata Nello Carrara (Italy); V. V. Tuchin, N.G. Chernyshevsky Saratov State Univ. (Russian Federation)

$7911 \mathrm{HH} \quad$ Biological sensing with surface-enhanced Raman spectroscopy (SERS) using a facile and rapid silver colloid-based synthesis technique [7911-52]

C. Smyth, S. Mehigan, Y. P. Rakovich, Trinity College Dublin (Ireland); S. E. J. Bell, Queen's Univ. Belfast (United Kingdom); E. M. McCabe, Trinity College Dublin (Ireland)

791111 SILVER nano-cylinders designed by EBL used as label free LSPR nano-biosensors [791 1-53] N. A. Cinel, S. Bütün, E. Özbay, Bilkent Univ. (Turkey)

Author Index 
Downloaded From: https://www.spiedigitallibrary.org/conference-proceedings-of-spie on 26 Apr 2023

Terms of Use: https://www.spiedigitallibrary.org/terms-of-use 


\title{
Conference Committee
}

\author{
Symposium Chairs \\ James G. Fujimoto, Massachusetts Institute of Technology (United \\ States) \\ R. Rox Anderson, Wellman Center for Photomedicine, Massachusetts \\ General Hospital, Harvard School of Medicine (United States)
}

Program Track Chairs

Paras Prasad, SUNY/Buffalo (United States)

Dan V. Nicolau, The University of Liverpool (United Kingdom)

Conference Chairs

Tuan Vo-Dinh, Duke University (United States)

Joseph R. Lakowicz, University of Maryland School of Medicine (United States)

Session Chairs

$1 \quad$ Surface Enhanced Raman Scattering

Tuan Vo-Dinh, Duke University (United States)

2 Surface Plasmon Resonance and Sensing I

Laura M. Lechuga, Centre d'Investigacions en Nanociència i Nanotecnologia (Spain)

3 Surface Plasmon Resonance and Sensing II

Julien Moreau, Laboratoire Charles Fabry (France)

4 Applications of Plasmonics I

Volker Deckert, Institut für Photonische Technologien e.V. (Germany)

5 Applications of Plasmonics II

Volker Deckert, Institut für Photonische Technologien e.V. (Germany)

6 Fluorescence, Plasmonics, and Imaging

Ho-Pui Ho, The Chinese University of Hong Kong (Hong Kong, China) 
$7 \quad$ Imaging and Plasmonics

Julien Moreau, Laboratoire Charles Fabry (France)

8 Plasmonics, Structures, and Photophysics

Jiri Homola, Institute of Photonics and Electronics of the ASCR, v.v.i. (Czech Republic) 